(c) American Dairy Science Association, 2004.

\title{
Structural Analysis of a New Anti-Hypertensive Peptide ( $\beta$-Lactosin B) Isolated from a Commercial Whey Product
}

\author{
M. Murakami, ${ }^{1}$ H. Tonouchi, ${ }^{2}$ R. Takahashi, ${ }^{1}$ H. Kitazawa, ${ }^{1}$ Y. Kawai, ${ }^{1}$ H. Negishi, ${ }^{3}$ and T. Saito ${ }^{1}$ \\ ${ }^{1}$ Laboratory of Animal Products Chemistry, Graduate School of Agricultural Science, Tohoku University, 1-1, \\ Tsutsumidori - Amamiyamachi, Aoba-ku, Sendai 981-8555, Japan \\ ${ }^{2}$ Meiji Dairies Corporation, 540, Naruda, Odawara, Kanagawa 250-0862, Japan \\ ${ }^{3}$ Meiji Kenko Ham Co., Ltd., 5-21-12, Minamioi, Shinagawa-ku, Tokyo 140-0013, Japan
}

\begin{abstract}
Angiotensin-converting enzyme (ACE) inhibitory activities and anti-hypertensive activities in spontaneously hypertensive rats (SHR) of 12 kinds of commercial peptides of food additive grade were measured. Four peptide products derived from milk proteins showed strong anti-hypertensive activities $(>-18.0 \mathrm{~mm} \mathrm{Hg})$. A sample of WE80BG derived from whey proteins showed the strongest anti-hypertensive activity $(-21.2 \pm 16.9$ $\mathrm{mm} \mathrm{Hg}$ ) with a medium level of ACE inhibitory activity (53.6\%), and it was subjected to hydrophobic and gel filtration chromatography. From the low molecular weight fraction, an anti-hypertensive peptide was isolated by using reversed-phase HPLC, and it was found to be a tetrapeptide, alanine-leucine-proline-methionine (Ala-Leu-Pro-Met, ALPM), the origin of which was estimated to be $\beta$-lactoglobulin f 142 to 145 . At $8 \mathrm{~h}$ after oral administration of ALPM in SHR, systolic blood pressure was significantly decreased $(-21.4 \pm 7.8 \mathrm{~mm}$ $\mathrm{Hg}$ ), but the $\mathrm{IC}_{50}$ value (concentration of peptide needed to inhibit 50\% of the ACE activity) of ALPM was not so high. We named the Ala-Leu-Pro-Met " $\beta$-lactosin B." This peptide is the second anti-hypertensive peptide found from $\beta$-lactoglobulin. Because WE80BG containing ALPM was also found to show the strongest anti-hypertensive activity $(-24.5 \pm 10 \mathrm{~mm} \mathrm{Hg})$ at $8 \mathrm{~h}$ after oral administration in SHR, WE80BG would be suitable for application to the development of a new food expected to have anti-hypertensive effects.
\end{abstract}

(Key words: whey, anti-hypertensive peptide, angiotensin-converting enzyme)

Abbreviation key: $\mathbf{A C E}=$ angiotensin-converting en-
zyme, ALPM = Ala-Leu-Pro-Met, $\mathbf{I C}_{\mathbf{5 0}}=$ concentration
of peptide needed to inhibit $50 \%$ of the ACE activity,
$\mathbf{R P}=$ reversed phase, $\mathbf{S B P}=$ systolic blood pressure,
$\mathbf{S H R}=$ spontaneously hypertensive rats, TFA = triflu-
oroacetic acid.

Received January 15, 2004.

Accepted February 18, 2004.

Corresponding author: T. Saito; e-mail: tsaito@bios.tohoku.ac.jp.

\section{INTRODUCTION}

Many biologically active peptides have been identified from milk proteins and dairy products by proteolysis with digestive enzymes or microbial enzymes or by fermentation; they have shown various bioactivities such as opioid, anti-hypertensive, mineral-binding, antithrombotic, and immunomodulatory activities (Meisel, 1998; Korhonen and Pihlanto-Leppälä, 2001).

Angiotensin-converting enzyme (ACE; peptidyldipeptide hydolase, EC 3.4.15.1) plays an important role in the regulation of blood pressure in mammmals. The ACE cleaves the C-terminal dipeptide of angiotensin I and produces the vasoconstrictor angiotensin II. The ACE also inactivates the vasodilator bradykinin. Many food proteins have peptide sequences with potential ACE-inhibitory activities, and there are many reports of ACE inhibitory peptides derived from milk proteins and various food proteins (FitzGerald and Meisel, 2000; Kitts and Weiler, 2003). Spontaneously hypertensive rats (SHR) have been widely used to evaluate antihypertensive activities in vivo. In our previous studies, 7 kinds of anti-hypertensive peptides were derived from cheese whey protein after protease $\mathrm{K}$ digestion (Abubakar et al., 1996; Saito et al., 1997; Abubakar et al., 1998), and 4 kinds of anti-hypertensive peptides were found in Gouda cheese (Saito et al., 2000). Milk fermented by Lactobacillus helveticus CPN4, including ACE-inhibitory peptides isoleucyl-prolyl-proline and valyl-prolyl-proline, also showed anti-hypertensive activity in SHR (Yamamoto et al., 1999) and in hypertensive subjects (Hata et al., 1996). Milk fermented by Lactobacillus helveticus LBH-16H also had a blood pressure-lowering effect in animal models (Sipola et al., 2001) and in humans (Seppo et al., 2003).

A new category of foods termed Food for Specified Health Uses is now commercially available in Japan. Permission was obtained from the Japanese Ministry of Health, Labor and Welfare in 1997 to advertise these products as health-promoting products. Although ACEinhibitory peptides and anti-hypertensive peptides have been reported, only 8 kinds of ACE-inhibitory peptides or ACE-inhibitory components are used for each 
Table 1. Twelve commercial peptide products used in this study.

\begin{tabular}{llcll}
\hline Peptide $^{1}$ & Origin & $\begin{array}{l}\text { Average molecular } \\
\text { weight }(\mathrm{Da})\end{array}$ & $\begin{array}{l}\text { Protein } \\
\text { content }(\%)\end{array}$ & $\begin{array}{l}\text { Solubility in } \\
\text { water }(\mathrm{g} / \mathrm{L})\end{array}$ \\
\hline WE80BG & Whey protein & 570 & 81.5 & 700 \\
WE80M & Whey protein & 3000 & 79.4 & 350 \\
WE90FS & Whey protein & 8500 & 90.0 & - \\
LE80GF & Whey protein & 4600 & 77.2 & 150 \\
CE90STL & Casein & 400 & 86.7 & 300 \\
CE90GMM & Casein & 640 & 89.9 & 250 \\
CE90F & Casein & 18,500 & 91.2 & 200 \\
EE90FX & Ovalbumin & 2000 & 85.9 & 150 \\
WGE80GPA & Wheat gluten & 660 & 77.6 & 200 \\
WGE80GPN & Wheat gluten & 670 & 79.0 & 400 \\
WGE80GPU & Wheat gluten & 6700 & 53.5 & 200 \\
SE50BT & Soybean protein & 320 & & 300 \\
\hline
\end{tabular}

${ }^{1}$ All peptides are commercially available from DMV JAPAN (Tokyo).

product. Furthermore, only 2 kinds of milk-derived peptides are included in these products. It may be difficult to produce these peptides in these products with stability on an industrial scale. Milk proteins are used as food ingredients for various products.

In this study, we report the isolation and results of structural analysis of anti-hypertensive peptides from commercial peptide products as food additives and discuss their applicability for design of foods.

\section{MATERIALS AND METHODS}

\section{Materials}

Twelve peptide samples were gifts from DMV JAPAN (Tokyo, Japan).

Their origins, average molecular weights, protein contents, and degrees of solubility are listed in Table 1. An ACE (EC 3.4.15.1 from bovine lung), standard amino acid H-type (each $2.5 \mu \mathrm{mol} / \mathrm{mL}$ in $0.1 N \mathrm{HCl}$ ), trifluoroacetic acid (TFA) for HPLC, triethylamine, and phenylisothiocyanate for amino acid composition analysis were purchased from Wako Pure Chemical Co., Ltd. (Osaka, Japan). Hippuryl-histidyl-leucine as the substrate for ACE was obtained from Sigma Chemical Co., Ltd. (St. Louis, MO). Constant-boiling $6 N \mathrm{HCl}$ for acid hydrolysis was purchased from Pierce (Rockford, IL), and $\mathrm{CH}_{3} \mathrm{CN}$ of HPLC grade was purchased from Kanto Chemical Co., Ltd. (Tokyo, Japan). Other chemicals of analytical grade were obtained from Wako Pure Chemical. Chemical synthesis of peptides with $\mathrm{N}-\alpha-9$ fluorenylmethoxycarbonyl-derived amino acids was conducted by Qiagen (Tokyo, Japan).

\section{Experimental Animals}

Spontaneously hypertensive rats (males; 10 wk of age) were purchased from Japan SLC, Inc. (Hamamatsu, Japan). The rats were housed in cages on a 14-h light and 10-h dark cycle. The temperature and humidity conditions were controlled at $24 \pm 1^{\circ} \mathrm{C}$ and $60 \pm$ $3 \%$, respectively. The rats were fed standard laboratory "Labo MR Breeder" (Nihon Nosan Kogyo Co., Ltd., Yokohama, Japan) and distilled water ad libitum.

\section{Measurement of ACE Inhibitory Activity (In Vitro)}

The ACE inhibitory activity was measured according to the method described previously (Abubakar et al., 1996, 1998). Each peptide solution $(75 \mu \mathrm{g} / 150 \mu \mathrm{L})$ was mixed with a borate buffer ( $\mathrm{pH}$ 8.3) containing 12.5 $\mathrm{m} M$ hippuryl-L-histidyl-leucine and $1.0 \mathrm{M} \mathrm{NaCl}$. After addition of $5 \mathrm{mU}$ of ACE, the mixture was incubated at $37^{\circ} \mathrm{C}$ for $45 \mathrm{~min}$. The reaction was stopped by addition of $250 \mu \mathrm{L}$ of $0.5 \mathrm{~N} \mathrm{HCl}$ solution. The liberated hipurric acid extracted with $1.5 \mathrm{~mL}$ of ethyl acetate was measured spectrophotometrically at $228 \mathrm{~nm}$ by a UV-VIS Spectrophotometer UV-1200 (Shimadzu Co., Ltd., Kyoto, Japan). The concentration of ACE inhibitory peptides that reduce ACE activity by $50 \%$ was defined as the $\mathbf{I C}_{\mathbf{5 0}}$ value.

\section{Measurement of Blood Pressure in SHR (In Vivo)}

Blood pressure in SHR was measured by our previously described method (Saito et al., 2000). Each rat was prewarmed in a thermostatted box at $40^{\circ} \mathrm{C}$ for 10 min, and systolic blood pressure (SBP) was measured by the tail cuff method with a programmed electrosphygmomanometer (model UR-5000; Ueda Co. Ltd., Tokyo, Japan). After $6 \mathrm{~h}$ of oral administration of the sample ( $2 \mathrm{mg} / 2 \mathrm{~mL}$ of distilled water) by direct gastric intubation, SBP was measured in each rat. Two milliliters of distilled water were used as a control. Results are expressed as means and SE. 


\section{Purification of Anti-hypertensive Peptides}

Each commercial peptide product ( $1 \mathrm{~g}$ ) was dissolved in distilled water $(200 \mathrm{~mL})$ and then mixed with $100 \mathrm{~g}$ of Wakogel LP-40C18 resin (particle size, 20 to $40 \mu \mathrm{m}$; Wako Pure Chemical). After vigorous shaking, hydrophobic peptides absorbed to the resin were recovered by elution with $200 \mathrm{~mL}$ of $90 \%$ (vol/vol) $\mathrm{C}_{2} \mathrm{H}_{5} \mathrm{OH}$ solution. After removal of $\mathrm{C}_{2} \mathrm{H}_{5} \mathrm{OH}$ by rotary evaporation at $<40^{\circ} \mathrm{C}$, each peptide sample was lyophilized.

The hydrophobic peptides prepared from a WE80BG sample were fractionated by gel filtration chromatography with a Sephadex G-15 column $(2.6 \times 90 \mathrm{~cm}$; bed volume, $478 \mathrm{~mL}$; Amarsham Pharmacia Biotech, Co., Ltd, Uppsala, Sweden) by using $0.05 \%$ (vol/vol) TFA solution under detection at $214 \mathrm{~nm}$. Bovine serum albumin and glycine (molecular weight $=75$ ) were used as markers to determine the eluting positions of peptides and amino acids. The fraction showing anti-hypertensive activity was further purified by HPLC with a reversed-phase (RP) mode. Chromatography was carried out with an intelligent pump (L-6200; Hitachi Co. Ltd., Tokyo, Japan), by using a Wakosil-II 5C18 column (4.6 $\times 150 \mathrm{~mm}$; Wako Pure Chemical). The peptides were eluted by a linear gradient method from Solvent A $\left(0.05 \%\right.$ TFA in $\left.10 \% \mathrm{CH}_{3} \mathrm{CN}\right)$ to $60 \%$ of solvent $\mathrm{B}(0.05 \%$ TFA in $60 \% \mathrm{CH}_{3} \mathrm{CN}$ ) over a period of $15 \mathrm{~min}$ at a flow rate of $0.5 \mathrm{~mL} / \mathrm{min}$ and detected at $214 \mathrm{~nm}$ with a UV and visible light detector (L-7420; Hitachi) that was linked to a data station (D-5500; Hitachi).

\section{Chemical Analysis}

The purity of a peptide was analyzed by capillary electrophoresis with a BioFocus 3000 (Bio-Rad Laboratories, Richmond, VA) equipped with a coated column (25 $\mu \mathrm{m} \times 17 \mathrm{~cm}$; no.148 to 3031; Bio-Rad Laboratories) in the presence of $0.1 M$ phosphate buffer ( $\mathrm{pH} 2.5$; no. 148 to 5011; Bio-Rad Laboratories) at $10 \mathrm{kV}$ for $15 \mathrm{~min}$. The carousel temperature was maintained at $20^{\circ} \mathrm{C}$, and the column effluent was detected at $200 \mathrm{~nm}$.

Amino acid composition analysis of the peptide was done according to the method of Bidlingmeyer et al. (1984) with some modifications. The peptide was hydrolyzed by the gas phase method with constant-boiling $\mathrm{HCl}$ containing $10 \%$ (vol/vol) phenol in a dry block bath (MG-2; Japan Torika Ltd., Tokyo, Japan) at $108^{\circ} \mathrm{C}$ for $24 \mathrm{~h}$. Phenylthiocarbamyl amino acids were analyzed by HPLC using an intelligent pump (L-6200) with a Wakosil-II 5 C18 column $(4.6 \mathrm{~mm} \times 250 \mathrm{~mm})$ at $254 \mathrm{~nm}$. The peptide was eluted by a linear gradient method from Solvent A ( $140 \mathrm{mM}$ sodium acetate buffer; $\mathrm{pH}$ 5.4) to $50 \%$ of Solvent $\mathrm{B}\left(60 \% \mathrm{CH}_{3} \mathrm{CN}\right)$ over a period of 30 min at a flow rate of $1.0 \mathrm{~mL} / \mathrm{min}$ and was detected at $254 \mathrm{~nm}$.
Table 2. Angiotensin-converting enzyme (ACE) inhibitory and antihypertensive activities determined in 12 commercial peptide products.

\begin{tabular}{|c|c|c|}
\hline Peptide & $\begin{array}{l}\text { ACE inhibitory } \\
\text { activity }^{1}(\%)\end{array}$ & $\begin{array}{l}\text { Anti-hypertensive } \\
\text { activity }^{2}(\mathrm{~mm} \mathrm{Hg})\end{array}$ \\
\hline WE80BG & 53.6 & $-21.2 \pm 16.9$ \\
\hline WE80M & 78.2 & $-18.8 \pm 9.4$ \\
\hline WE90FS & 45.1 & $-8.5 \pm 19.1$ \\
\hline LE80GF & 41.9 & $+0.8 \pm 13.5$ \\
\hline CE90STL & 64.9 & $-20.7 \pm 10.3$ \\
\hline CE90GMM & 51.3 & $-18.0 \pm 19.3$ \\
\hline CE90F & 34.1 & $-12.0 \pm 11.4$ \\
\hline EE90FX & 78.2 & $-0.5 \pm 3.3$ \\
\hline WGE80GPA & 62.7 & $-5.8 \pm 8.4$ \\
\hline WGE80GPN & 59.7 & $-17.2 \pm 9.1$ \\
\hline WGE80GPU & 36.0 & $-10.0 \pm 2.5$ \\
\hline SE50BT & 37.3 & $-4.5 \pm 6.7$ \\
\hline
\end{tabular}

${ }^{1}$ Mean of ACE inhibitory activity (\%) in duplicate experiments.

${ }^{2}$ Dose was $2 \mathrm{mg}$ of peptides/ $2 \mathrm{~mL}$ of distilled water. Changes in systolic blood pressure were measured with spontaneously hypertensive rats and were determined $6 \mathrm{~h}$ after oral administration $(\mathrm{n}=3)$. Results are expressed as means $\pm \mathrm{SE}$.

The peptide was sequenced by automated Edman degradation using a protein sequencer (Procise 490; Perkin Elmer Co. Ltd., Applied Biosystem Division, Foster, CA $)$ with a PTH-C18 column $(2.1 \mathrm{~mm} \times 220$ $\mathrm{mm}$; Perkin Elmer). Chemicals used in the 140C Microgradient Delivery System included 2 kinds of solvent (Perkin Elmer): A3 (3.5\% [vol/vol] aqueous tetrahydrofuran) and $\mathrm{B}\left(\mathrm{CH}_{3} \mathrm{CN}\right.$ and isopropanol).

The molecular mass of the peptide was analyzed by fast atom bombardment-mass spectrometry with glycerol as a matrix under a positive mode at a low resolution of $8 \mathrm{kV}$.

\section{RESULTS}

\section{ACE Inhibitory Activity and Anti-hypertensive Effect}

The ACE inhibitory and anti-hypertensive activities were determined in samples of 12 kinds of peptides that are commercially available in Japan (Table 2). Samples of WE80M and EE90FX, derived from whey protein and ovalbumin, respectively, showed the highest level of ACE inhibitory activity (78.2\%). The WE80BG and WE90FS, derived from whey protein, did not show such strong ACE inhibitory activities. Samples of 4 peptides derived from milk proteins (WE80BG, WE80M, CE90STL, and CE90GMM) showed strong anti-hypertensive effects $(>-18.0 \mathrm{~mm} \mathrm{Hg}$ ) with medium levels of ACE inhibitory activities ( $>51.0 \%)$. Although the ACE inhibitory activity level of EE90FX was very high, its anti-hypertensive activity was very weak $(-0.5 \pm 3.3$ $\mathrm{mm} \mathrm{Hg}$ ). Because WE80BG showed the strongest antihypertensive activity $(-21.2 \pm 16.9 \mathrm{~mm} \mathrm{Hg})$, it was sub- 


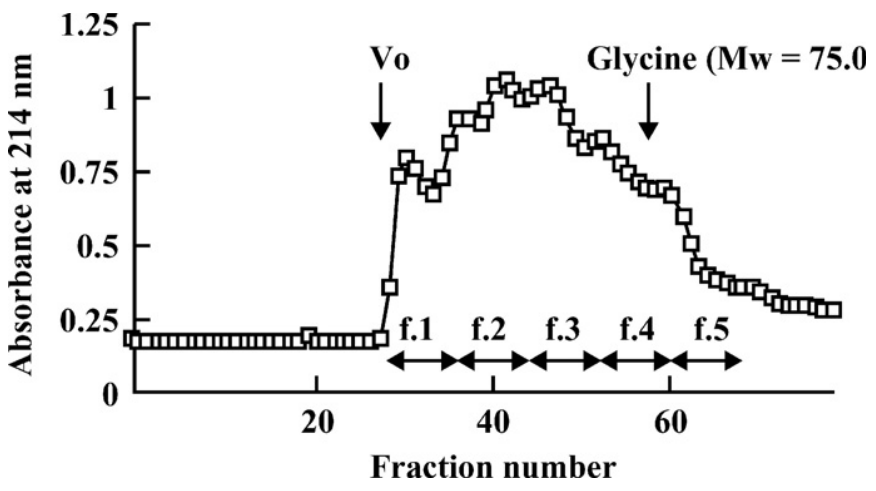

Figure 1. Fractionation of hydrophobic peptides prepared from WE80BG by gel filtration chromatography. Column: Sephadex G-15 column $(2.6 \times 90 \mathrm{~cm})$, elution: $0.05 \%(\mathrm{vol} / \mathrm{vol})$ trifluoroacetic acid solution, flow rate: $0.5 \mathrm{~mL} / \mathrm{min}$, fractionation: $5 \mathrm{~mL}$, and detection: $214 \mathrm{~nm}$. To determine the void volume and the elution time of amino acid, bovine serum albumin and L-glycine (molecular weight $[\mathrm{Mw}]=$ 75) were used as markers.

jected to subsequent structural analysis. The $\mathrm{IC}_{50}$ value of WE80 BG was $352 \mu \mathrm{g} / \mathrm{mL}$.

\section{Purification of Anti-hypertensive Peptides}

A sample of WE80BG was subjected to hydrophobic chromatography with Wakogel LP40C18 resin, and the hydrophobic peptides absorbed to the resin were eluted with $90 \% \mathrm{C}_{2} \mathrm{H}_{5} \mathrm{OH}$ solution. The hydrophobic peptides were fractionated by gel filtration chromatography with Sephadex G-15 (Figure 1). The peptides were fractionated into 5 fractions (f.1 to f.5) according to molecular weight, and each fraction was subjected to the following assay. Fraction f.4 showed the strongest anti-hypertensive activity $(-18.8 \pm 6.8 \mathrm{~mm} \mathrm{Hg})$ with a medium level of ACE inhibitory activity (42.5\%; Figure 2). Fraction f. 4 was further purified by RP HPLC and divided into 5 fractions, a, b, c, d, and e according to the eluting order (Figure 3 ). The peptide of fraction d, which eluted a single peak, showed the highest level of ACE inhibitory activity $(55.2 \%)$, and the other fractions did not show ACE inhibitory activity (fractions a, b, and e: 0\%; fraction c: $6.3 \%$ ). Finally, the purity of peptide $d$ was confirmed by capillary electrophoresis (Figure 4), and it was subjected to the structural analysis.

\section{Structural Analysis of an Anti-hypertensive Peptide}

Results of amino acid composition analysis showed that peptide $d$ consisted of 4 kinds of amino acid: alanine, proline, leucine, and methionine. Through N-terminal analysis by Edman degradation, the sequence of peptide d was shown to be alanine-leucine-prolinemethionine (Ala-Leu-Pro-Met). The molecular weight
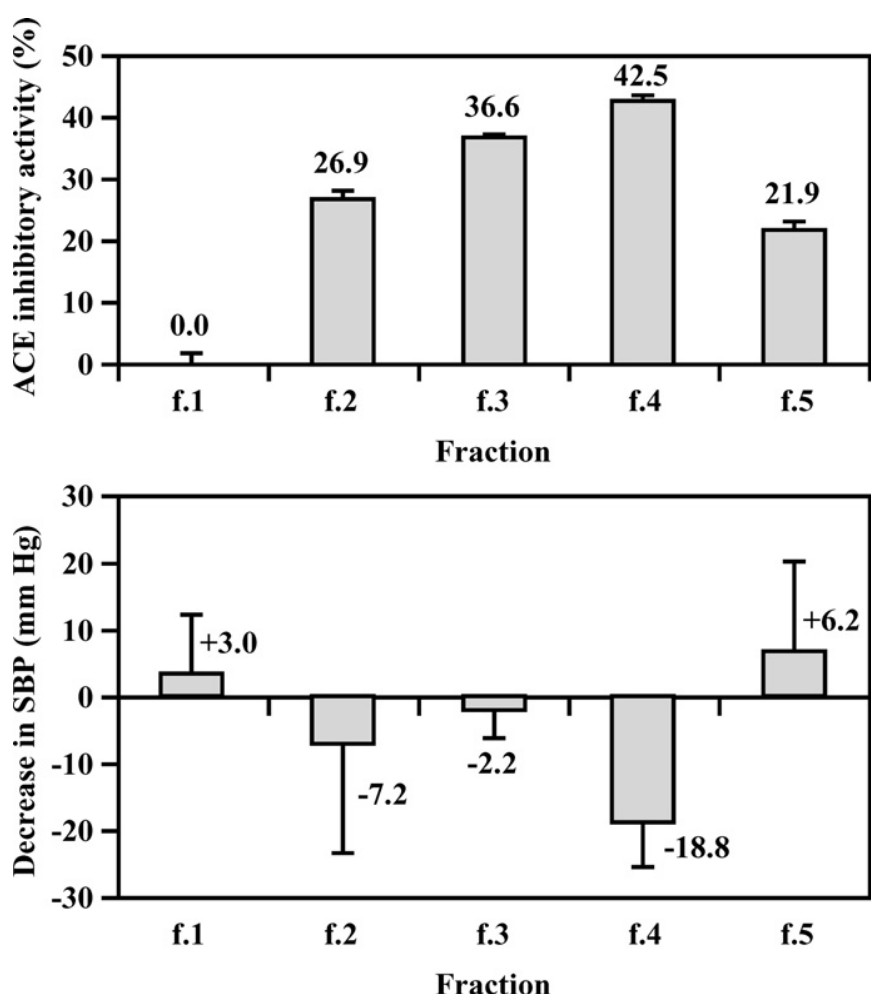

Figure 2. Angiotensin-converting enzyme inhibitory activity and anti-hypertensive effects in spontaneously hypertensive rats (SHR) detected in 5 fractions separated from gel filtration. The systolic blood pressure (SBP) in SHR was measured $6 \mathrm{~h}$ after oral administration, and each dose was $2 \mathrm{mg}$ of peptides $/ 2 \mathrm{~mL}$ of distilled water.

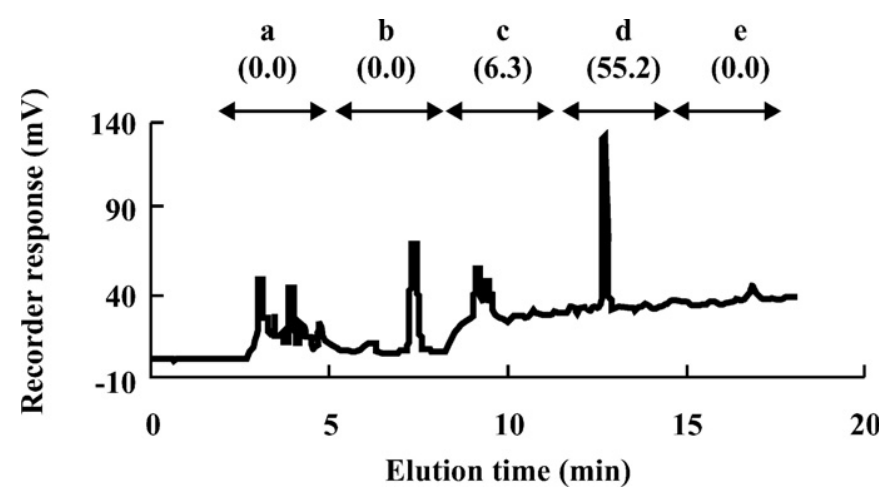

Figure 3. Isolation of anti-hypertensive peptides from the f.4 fraction by HPLC with reversed-phase mode. Column: Wakosil-II 5C18 $(4.6 \times 150 \mathrm{~mm} ; 5(\mu \mathrm{m})$, elution: linear gradient from $100 \%$ of Solvent $\mathrm{A}\left(10 \% \mathrm{CH}_{3} \mathrm{CN}\right.$ containing $0.05 \%$ trifluoroacetic acid [TFA]) to $80 \%$ of Solvent B ( $60 \% \mathrm{CH}_{3} \mathrm{CN}$ containing $0.05 \%$ TFA) over a period of 15 min at $40^{\circ} \mathrm{C}$, flow rate: $0.5 \mathrm{~mL} / \mathrm{min}$, and detection: $214 \mathrm{~nm}$. Numbers in parentheses represent the determined values of angiotensin-converting enzyme inhibitory activity (\%). 


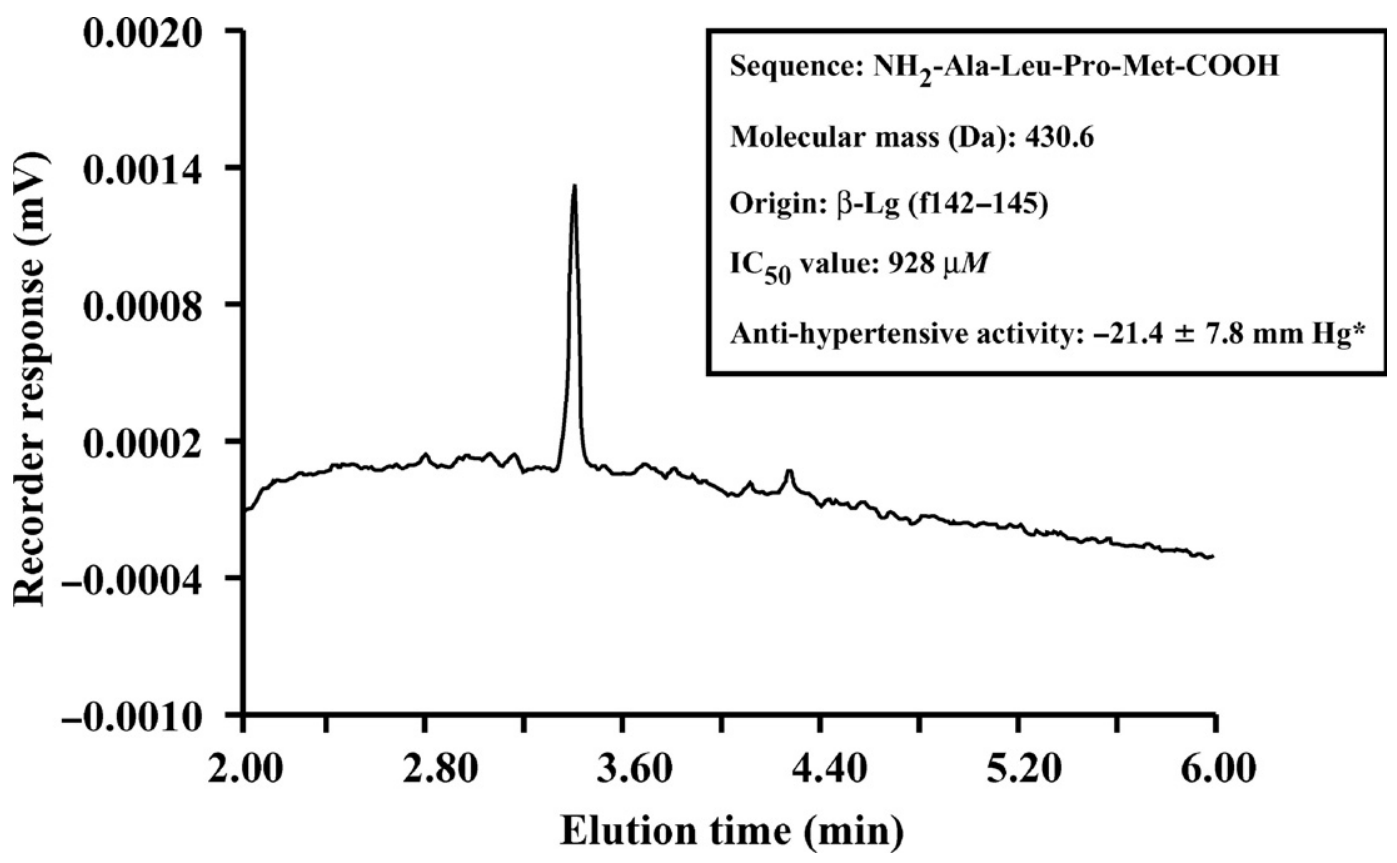

Figure 4. Elution profile of peptide d. The data were recorded by using a BioFocus 3000 (Bio-Rad Laboratories, Richmond, VA) equipped with a coated column $(25 \mu \mathrm{m} \times 17 \mathrm{~cm})$ in $0.1 M$ phosphate buffer $(\mathrm{pH} 2.5)$ at $10.00 \mathrm{kV}$ for 15 min. Each peptide was monitored at $200 \mathrm{~nm}$, and the carousel was maintained at $20^{\circ} \mathrm{C}$. By analysis of the anti-hypertensive peptide, the structure and origin of the peptide were determined. Its $\mathrm{IC}_{50}$ value (concentration of peptide needed to inhibit $50 \%$ of the angiotensin-converting enzyme activity) and anti-hypertensive activity were measured. The change in systolic blood pressure was measured in spontaneously hypertensive rats $(\mathrm{n}=5)$ at $8 \mathrm{~h}$ after administration. The dose was $1 \mathrm{mg}$ of peptide/ $1 \mathrm{~mL}$ of distilled water. *Significant difference from the control $(P<0.05)$.

of peptide d was determined to be $431.0(\mathrm{~m} / \mathrm{z})$ by fast atom bombardment-mass spectrometry, and it was considered to be a molecular ion $\left(\mathrm{M}^{+}+\mathrm{H}\right)$. The tetrapeptide was thought to be originated from $\beta$-lactoglobulin ( 142 to 145 ). The primary structure, molecular weight, and origin of the peptide are shown in Figure 4.

\section{Bioactivity of a Tetrapeptide Isolated from WE80BG}

To determine the $\mathrm{IC}_{50}$ value and anti-hypertensive activity, the tetrapeptide Ala-Leu-Pro-Met was chemically synthesized according to information obtained from structural analyses. Chemically synthesized AlaLeu-Pro-Met showed an $\mathrm{IC}_{50}$ value of $928 \mu \mathrm{M}$ (Figure 4). Changes in SBP were measured in SHR $(n=5)$ at $2,4,6,8,10$, and $24 \mathrm{~h}$ after administration of chemically synthesized Ala-Leu-Pro-Met (Figure 5). At 6 and $8 \mathrm{~h}$ after administration, SBP was decreased to $-19.0 \pm 8.6$ and $-21.4 \pm 7.8 \mathrm{~mm} \mathrm{Hg}$, respectively, with a significant difference $(P<0.05)$ compared with that of the control. The blood pressure began to decrease after $2 \mathrm{~h}$ and had almost recovered to the initial value after $10 \mathrm{~h}$.

To confirm the anti-hypertensive activity, the safety, and the future availability of WE80BG, changes in SBP were determined in normotensive Wistar rats and SHR at $2,4,6,8$, and $10 \mathrm{~h}$ after oral administration (Figure
6). In Wistar rats, the decrease in SBP was greatest $(-15.0 \pm 6.4 \mathrm{~mm} \mathrm{Hg})$ at $6 \mathrm{~h}$ after administration of WE80BG, but a significant difference from that of the control was not found. In SHR, SBP decreased ( -24.5 $\pm 10.8 \mathrm{~mm} \mathrm{Hg})$ with a significant difference $(P<0.01)$

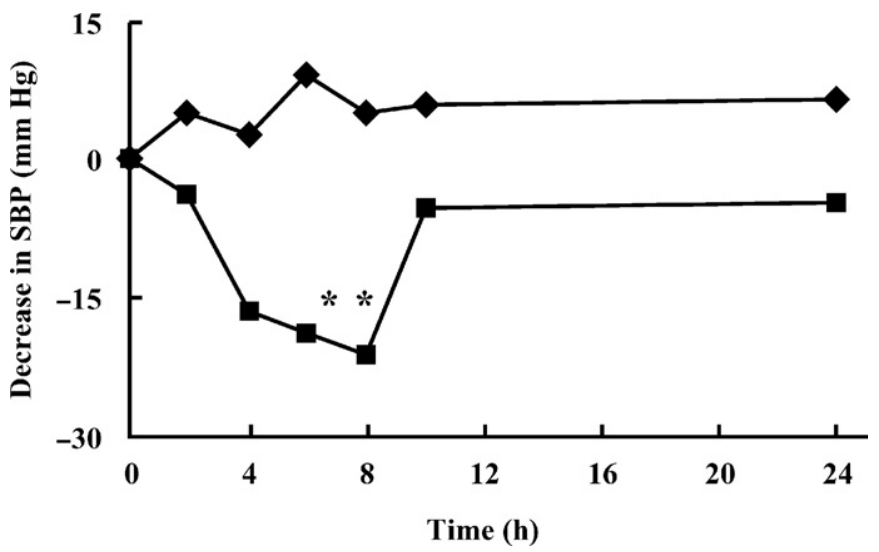

Figure 5. Changes in systolic blood pressure (SBP) were measured in spontaneously hypertensive rats $(\mathrm{n}=5)$ at $2,4,6,8,10$, and 24 $\mathrm{h}$ after administration. The dose was $1 \mathrm{mg}$ of alanine-leucine-prolinemethionine $/ 1 \mathrm{~mL}$ of distilled water. Control $=\diamond$; alanine-leucineproline-methionine $=\mathbf{\square}$. *Significant difference from the control $(P$ $<0.05)$. 
$\mathbf{A}$

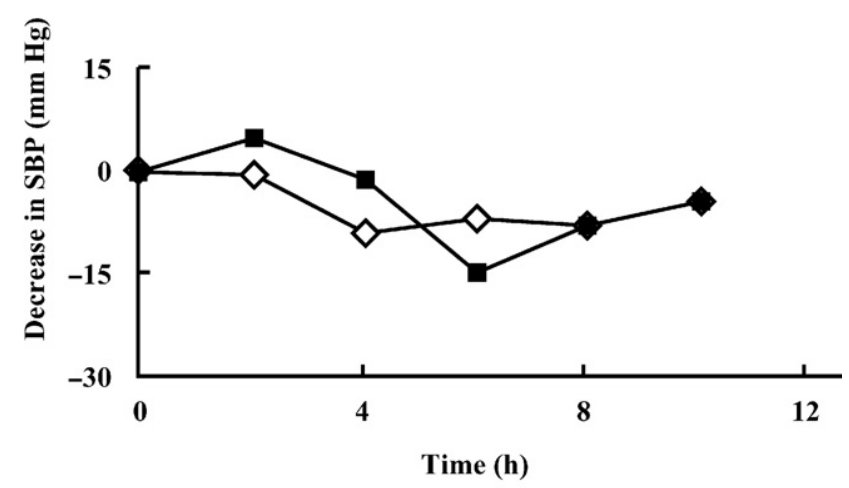

B

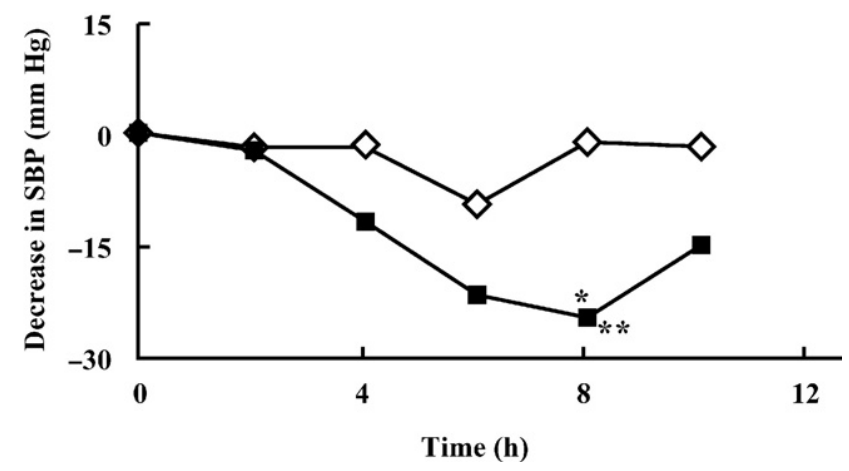

Figure 6. Changes in systolic blood pressure (SBP) in Wistar rats $(\mathrm{n}=4)(\mathrm{A})$ and spontaneously hypertensive rats $(\mathrm{n}=4)(\mathrm{B})$ at 2,4 , 6,8 , and $10 \mathrm{~h}$ after oral administration. The dose was $2 \mathrm{mg} / 2 \mathrm{~mL}$ of distilled water. Control (distilled water) $=\diamond ; \mathrm{WE} 80 \mathrm{BG}=\mathbf{\square}$. *Significant difference from the control $(P<0.05)$. **Significant difference from the Wistar rats administered WE80BG $(P<0.01)$.

from that of the control at $8 \mathrm{~h}$ after administration of WE80BG. This anti-hypertensive effect continued after $10 \mathrm{~h}$.

\section{DISCUSSION}

In this study, we identified an anti-hypertensive tetrapeptide, Ala-Leu-Pro-Met, from a commercial whey product, WE80BG, that originated from a sequence of 142 to 145 amino acid residues in $\beta$-lactoglobulin (f 142 to 145 ). We named this peptide " $\beta$-lactosin B" according to the term used in our previous paper for an antihypertensive peptide, " $\beta$-lactosin A," from $\beta$-lactoglobulin $\mathrm{f} 78$ to 80 (Abubakar et al., 1998). Chemically synthesized $\beta$-lactosin $\mathrm{B}$ showed a high $\mathrm{IC}_{50}$ value of $928 \mu \mathrm{M}$, indicating weak ACE inhibitory activity. The $\mathrm{IC}_{50}$ values of a series of peptides, including Ala-Leu-Pro-Met, are summarized in Table 3. Mullally et al. (1997) reported that the ACE inhibitory heptapeptide "lactokinin" ( $\beta$-lactoglobulin $f 142$ to 148 ) derived by tryptic
Table 3. Primary structures, origins and $\mathrm{IC}_{50}$ values (concentration of peptide needed to inhibit $50 \%$ of the angiotensin-converting enzyme [ACE] activity) of the anti-hypertensive peptide alanine-leucine-proline-methionine and the relevant ACE inhibitory peptides.

\begin{tabular}{llc}
\hline Peptide & Origin & $\mathrm{IC}_{50}(\mu \mathrm{M})$ \\
\hline ALPM & $\beta-\mathrm{Lg}$ (f 142-145) & 928 \\
ALPMH $^{1}$ & $\beta-\mathrm{Lg}$ (f 142-146) & 521 \\
ALPMHIR $^{2}$ & $\beta-\mathrm{Lg}$ (f 142-148) & 42.6 \\
$\mathrm{LPMHIR}^{1}$ & $\beta-\mathrm{Lg}$ (f 143-148) & $\mathrm{ND}^{3}$ \\
$\mathrm{HIRL}^{4}$ & $\beta-\mathrm{Lg}(\mathrm{f} 146-149)$ & 1153 \\
$\mathrm{HIR}^{1}$ & $\beta-\mathrm{Lg}(\mathrm{f} 146-148)$ & 953 \\
$\mathrm{IR}^{3}$ & $\beta-\mathrm{Lg}$ (f 147-148) & 695 \\
\hline
\end{tabular}

${ }^{1}$ Pihlanto-Leppälä et al. (2000).

${ }^{2}$ Mullally et al. (1997).

${ }^{3} \mathrm{ND}=$ Not determined.

${ }^{4}$ Mullally et al. (1996).

hydrolysis from whey proteins showed a high $\mathrm{IC}_{50}$ value of $42.6 \mu M$. Pihlanto-Leppälä et al. (2000) reported that $\beta$-lactoglobulin f 142 to 146 had an $\mathrm{IC}_{50}$ value of 521 $\mu M$ and that a tripeptide, HIR ( $\beta$-lactoglobulin $\mathrm{f} 146$ to $148)$, had an $\mathrm{IC}_{50}$ value of $953 \mu M$. Although Ala-LeuPro-Met and HIR showed medium levels of ACE inhibitory activity, Ala-Leu-Pro-MetHIR showed strong ACE inhibitory activity.

The importance of hydrophobic amino acid residues in peptides for ACE inhibition has been discussed. Cheung et al. (1980) showed that hydrophobic amino acid residues such as aromatic (tryptophan, tyrosine, and phenylalanine) or imino (proline) amino acids at each of the $3 \mathrm{C}$-terminal positions contribute to the expression of ACE inhibitory activity of peptides. Ondetti and Cushman (1982) reported that the C-terminal tripeptide residues could interact with 3 subsites of ACE. Meisel (1998) suggested that a positive charge such as that of the guanidine group of Arg is important for ACE inhibition. For the first purification step of anti-hypertensive peptides from WE80BG, we selected hydrophobic peptides. Alanine-leucine-proline-methionine is composed of hydrophobic amino acid, and HIR has arginine and hydrophobic amino acid isoleucine. The sequences of both Ala-Leu-Pro-Met and HIR are considered to be important for ACE inhibition.

Although in vivo studies are important, there have been few in vivo studies on ACE inhibitory peptides derived from whey proteins. A number of ACE inhibitory peptides from the enzymatic hydrolysate of bovine casein have been reported, but some of those peptides did not show anti-hypertensive activity in SHR or normotensive Wistar rats (Maruyama et al., 1985; Maruyama et al., 1987a,b; Karaki et al., 1990). Although Ala-Leu-Pro-Met did not show strong ACE inhibitory activity, it had strong anti-hypertensive activity (-21.4 $\pm 7.8 \mathrm{~mm} \mathrm{Hg}$; Figure 4). Maeno et al. (1996) reported that the $\mathrm{IC}_{50}$ value of $\beta$-casein $\mathrm{f} 169$ to 175 was 1000 
$\mu M$, but that the activity of pancreatic digestive $\mathrm{f} 169$ to 174 was increased to $5 \mu M$, and anti-hypertensive activities of both peptides were strong. There are various possible reasons for this discordance between ACE inhibitory activity and anti-hypertensive activity. For example, this tetrapeptide would be digested by intestinal proteases or peptidases before absorption from the intestine, and the anti-hypertensive effect might be generated in this process. Vermeirssen et al. (2002) reported that lactokinin (Ala-Leu-Pro-MetHIR) was transported into Caco-2 cells as in the in vitro experiment, but it is generally accepted that di- and tripeptides are only absorbed through such as the intestinal oligopeptide transporter Pept-1 in human intestine (Adibi, 1997). Because elastase in pancreatic juice also cleaves the protein at the position of Ala-X or Leu$\mathrm{X}$, Ala + Leu-Pro-Met or Ala-Leu + Pro-Met will be generated from Ala-Leu-Pro-Met by elastase digestion. These small peptides must show anti-hypertensive activities.

Other anti-hypertensive mechanisms such as AT1receptor antagonist activity are also thought to be involved in the anti-hypertensive activity of Ala-Leu-ProMet. The biological effects of angiotensin II are mediated through the binding of AT1- or AT2-subtype receptors. The AT1-receptor is responsible for vasoconstriction and water intake. By blockade of the AT1-receptor, angiotensin II-mediated vascular contractile responses are inhibited. It is necessary to study the anti-hypertensive mechanism of Ala-Leu-Pro-Met in vitro in the future. Recently, multifunctional peptides have been reported: $\alpha$-lactorphin ( $\alpha$-lactalbumin f 50 to 53 ) and $\beta$ lactorphin ( $\beta$-lactoglobulin $\mathrm{f} 102$ to 105), which showed opioid-like activity (Yoshikawa et al., 1986) and ACE inhibitory activity with $\mathrm{IC}_{50}$ values of 733 and $172 \mu \mathrm{M}$ (Mullally et al., 1996), respectively. These opioid peptides improved vascular relaxation in SHR (Sipola et al., 2001), and $\alpha$-lactorphin lowered blood pressure in SHR (Nurminen et al., 2000). It is interesting that some bioactive peptides possess multiple functions simultaneously. Nagaoka et al. (2001) reported that Ala-LeuPro-MetH ( $\beta$-lactoglobulin f 142 to 146) inhibited cholesterol absorption in Caco-2 cell screening in vitro. The anti-hypertensive peptide Ala-Leu-Pro-Met in this study is also expected to have other functions. The antihypertensive activity level of Ala-Leu-Pro-Met was highest at $8 \mathrm{~h}$ after administration in SHR. Although the contribution of Ala-Leu-Pro-Met to the anti-hypertensive activity of WE80BG is not clear, it is thought that other anti-hypertensive peptides exist and work together with Ala-Leu-Pro-Met in WE80BG. Although WE80BG showed anti-hypertensive activity in both SHR and normotensive Wistar rats, the decrease in SBP was significantly greater in SHR. We conclude that commercial WE80BG may be useful for application to functional food for treatment of hypertension. Further studies on the anti-hypertensive mechanism of AlaLeu-Pro-Met and WE80BG are now in progress.

\section{ACKNOWLEDGMENTS}

We thank T. Yamada (Laboratory of Applied Bioorganic Chemistry, Graduate School of Agricultural Science, Tohoku University) for mass analysis of peptides. We also thank M. Yoshida of DMV Japan (Tokyo, Japan) for giving 12 peptide samples. This work was partially supported by a Grant-in-Aid for Scientific Research (B) (2) (No. 14360158) from the Ministry of Education, Science and Culture of Japan to T. Saito.

\section{REFERENCES}

Abubakar, A., T. Saito, M. V. Aimar, and T. Itoh. 1996. New derivation of the inhibitory activity against angiotensin converting enzyme (ACE) from sweet cheese whey. Tohoku J. Agric. Res. 47:1-8.

Abubakar, A., T. Saito, H. Kitazawa, Y. Kawai, and T. Itoh. 1998. Structural analysis of new antihypertensive peptides derived from cheese whey protein by proteinase K digestion. J. Dairy Sci. 81:3131-3138.

Adibi, S. A. 1997. The oligopeptide transporter (Pept-1) in human intestine: Biology and function. Gastroenterology 113:332-340.

Bidlingmeyer, B. A., S. A. Cohen, and T. L. Tarvin. 1984. Rapid analysis of amino acids using pre-column derivatization. J. Chromatogr. 336:93-104.

Cheung, H. S., F. L. Wang, M. A. Ondetti, E. F. Sabo, and D. W. Cushman. 1980. Binding of peptide substrates and inhibitors of angiotensin-converting enzyme. Importance of the $\mathrm{COOH}$-terminal dipeptide sequence. J. Biol. Chem. 255:401-407.

FitzGerald, R. J., and H. Meisel. 2000. Milk protein-derived peptide inhibitors of angiotensin-I-converting enzyme. Br. J. Nutr. 84:S33-S37.

Hata, Y., M. Yamamoto, M. Ohni, K. Nakajima, Y. Nakamura, and T. Takano. 1996. A placebo-controlled study of the effect of sour milk on blood pressure in hypertensive objects. Am. J. Clin. Nutr. 64:767-771.

Karaki, H., K. Doi, S. Sugano, H. Uchiwa, R. Sugai, U. Murakami, and S. Takemoto. 1990. Antihypertensive effect of tryptic hydrolysate of milk casein in spontaneously hypertensive rats. Comp. Biochem. Physiol. 96:367-371.

Kitts, D. D., and K. Weiler. 2003. Bioactive proteins and peptides from food sources. Applications of bioprocesses used in isolation and recovery. Curr. Pharm. 9:1309-1323.

Korhonen, H., and A. Pihlanto-Leppälä. 2001. Milk protein-derived bioactive peptides. Novel opportunities for health promotion. Bull. IDF 363:17-26.

Maeno, M., N. Yamamoto, and T. Takano. 1996. Identification of antihypertensive peptides from casein hydrolysate produced by a proteinase from Lactobacillus helveticus CP790. J. Dairy Sci. 79:1316-1321.

Maruyama, S., H. Mitachi, J. Awaya, M. Kurono, N. Tomizuka, and H. Suzuki. 1987a. Angiotensin I-converting enzyme inhibitory activity of the C-terminal hexapeptide of $\alpha_{\mathrm{s} 1}$-casein. Agric. Biol. Chem. 51:2557-2561.

Maruyama, S., H. Mitachi, H. Tanaka, N. Tomizuka, and H. Suzuki. 1987b. Studies on the active site and antihypertensive activity of angiotensin I-converting enzyme inhibitors derived from casein. Agric. Biol. Chem. 51:1581-1586.

Maruyama, S., K. Nakagomi, N. Tomizuka, and H. Suzuki. 1985. Angiotensin I-converting enzyme inhibitor derived from an enzymatic hydrolysate of casein. II. Isolation and bradykinin-potenti- 
ating activity on the uterus and the ileum of rats. Agric. Biol. Chem. 49:1405-1409.

Meisel, H. 1998. Overview on milk protein-derived peptides. Int. Dairy J. 8:363-373.

Mullally, M. M., H. Meisel, and R. J. FitzGerald. 1996. Synthetic peptides corresponding to alpha-lactalbumin and beta-lactoglobulin sequences with angiotensin-I-converting enzyme inhibitory activity. Biol. Chem. Hoppe-Seyler 377:259-260.

Mullally, M. M., H. Meisel, and R. J. FitzGerald. 1997. Identification of a novel angiotensin-I-converting enzyme inhibitory peptide corresponding to a tryptic fragment of bovine beta-lactoglobulin. FEBS Lett. 402:99-101.

Nagaoka, S., Y. Futamura, K. Miwa, T. Awano, K. Yamauchi, Y. Kanamaru, K. Tadashi, and T. Kuwata. 2001. Identification of novel hypocholesterolemic peptides derived from bovine milk beta-lactoglobulin. Biochem. Biophys. Res. Commun. 281:11-17.

Nurminen, M. L., M. Sipola, H. Kaarto, A. Pihlanto-Leppälä, K. Piilola, R. Korpela, O. Tossavainen, H. Korhonen, and H. Vapaatalo. 2000. $\alpha$-Lactorphin lowers blood pressure measured by radiotelementry in normotensive and spontaneously hypertensive rats. Life Sci. 66:1535-1543.

Ondetti, M. A., and D. W. Cushman. 1982. Enzymes of the reninangiotensin system and their inhibitors. Annu. Rev. Biochem. 51:283-308.

Pihlanto-Leppälä, A., P. Koskinen, K. Piilola, T. Tupasela, and H. Korhonen. 2000. Angiotensin I-converting enzyme inhibitory properties of whey protein digests: Concentration and characterization of active peptides. J. Dairy Res. 67:53-64.

Saito, T., A. Abubakar, T. Itoh, I. Arai, and M. V. Aimar. 1997. Development of a new type of fermented cheese whey beverage with inhibitory effects against angiotensin-converting enzyme. Tohoku J. Agric. Res. 48:15-23.

Saito, T., T. Nakamura, H. Kitazawa, Y. Kawai, and T. Itoh. 2000. Isolation and structural analysis of antihypertensive peptides that exist naturally in Gouda cheese. J. Dairy Sci. 83:1434-1440.

Seppo, L., T. Jauhiainen, T. Poussa, and R. Korpela. 2003. A fermented milk high in bioactive peptides has a blood pressurelowering effect in hypertensive subjects. Am. J. Clin. Nutr. 77:326-330.

Sipola, M., P. Finckenberg, J. Santisteban, R. Korpela, H. Vapaatalo, and M. L. Nurminen. 2001. Long-term intake of milk peptides attenuates development of hypertension in spontaneously hypertensive rats. J. Physiol. Pharmacol. 52:745-754.

Vermeirssen, V., B. Deplancke, K. A. Tappenden, J. Van Camp, H. R. Gaskins, and W. Verstraete. 2002. Intestinal transport of the lactokinin Ala-Leu-Pro-Met-His-Ile-Arg through a Caco-2 Bbe monolayer. J. Pept. Sci. 8:95-100.

Yamamoto, N., M. Maeno, and T. Takano. 1999. Purification and characterization of an antihypertensive peptide from a yogurtlike product fermented by Lactobacillus helveticus CPN4. J. Dairy Sci. 82:1388-1393.

Yoshikawa, M., F. Tani, T. Yoshimura, and H. Chiba. 1986. Opioid peptides from milk proteins. Agric. Biol. Chem. 50:2419-2421. 